\title{
Investigation on Relative Heat Losses and Gains of Heating and Cooling Networks
}

\author{
Violeta MADAN ${ }^{1 *}$, Ingo WEIDLICH ${ }^{2}$ \\ ${ }^{1,2}$ HafenCity University, Henning-Voscherau-Platz 1, Hamburg, 20457, Germany
}

\begin{abstract}
The integration of district heating (DH) and cooling (DC) in the sustainable energy system of the future requires a significant reduction in operating temperatures. Supply temperatures below $70^{\circ} \mathrm{C}$ are required for new $4^{\text {th }}$ Generation DH. Main benefits are the use of low exergy heat sources and the reduction of heat losses. The reduction of heat losses is achieved by reducing the driving temperature difference between the medium pipe and the ground. The decrease of the return temperature level is limited by the consumer behaviour and the ground temperature level. As a consequence, the reduction of the supply temperature is accompanied by a reduction of the maximum transmittable heat flow. For energy efficiency and economic reasons, the relative heat losses are therefore an important design value for $\mathrm{DH}$ networks. The study proposes an approach to estimate the relative heat losses by using steadystate heat loss models and analyses the values for different DH generations. In particular, due to the rising of the near-surface soil temperature, the relative cold losses are also studied.
\end{abstract}

Keywords - Cold losses; district cooling; district heating; heat losses

\begin{tabular}{|lll|}
\hline Nomenclature & & \\
$A$ & Cross-sectional area & $\mathrm{m}^{2}$ \\
$c_{p}$ & Heat capacity & $\mathrm{J} /(\mathrm{kgK})$ \\
$D$ & Half of the distance between the pipe axes & $\mathrm{m}$ \\
$d_{i}, d_{o}$ & Inner and outer insulation diameter & $\mathrm{m}$ \\
$h$ & Heat loss factor & - \\
$T$ & Temperature & $\mathrm{K}$ \\
$\dot{Q}$ & Heat flow rate & $\mathrm{W}$ \\
$q$ & Length related heat flow & $\mathrm{W} / \mathrm{m}$ \\
$v$ & Flow velocity & $\mathrm{m} / \mathrm{s}$ \\
$\lambda_{g}, \lambda_{i}$ & Heat conductivity of the ground and insulation & $\mathrm{W} /(\mathrm{mK})$ \\
$H$ & Burial depth & $\mathrm{m}$ \\
$R$ & Thermal Resistance & $\mathrm{mK} / \mathrm{W}$ \\
\hline
\end{tabular}

\section{INTRODUCTION}

District heating (DH) and district cooling (DC) can mainly contribute to a sustainable energy system based on renewable energy production. The temporal and local uncoupling of

\footnotetext{
${ }^{*}$ Corresponding author.

E-mail address: violeta.madan@hcu-hamburg.de 
the demand and supply are advantageous for the integration of renewable energy sources and the sector coupling approach [1]. Other benefits are the significant improvement of the energy efficiency for high population density areas and more flexible exchange of the energy source.

The development of $\mathrm{DH}$ extends over four generations and includes the optimization of materials, heat sources, pipe design and operating conditions. Decreasing of the operating temperature is one of the main objectives for newer DH generations, as a lower temperature level favours the integration of low temperature heat sources and the reduction of heat losses. Lund et al. define a supply temperature level below $100{ }^{\circ} \mathrm{C}$ for the $3^{\text {rd }}$ and $30-70{ }^{\circ} \mathrm{C}$ for the $4^{\text {th }}$ Generation DH [1].

The heat losses and gains are the main influencing parameters for design and efficiency of a DH or DC system. It is a major interest to minimize the heat losses (and gains in case of DC) for energy savings and economic reasons. Additional approaches to decrease heat losses are the improvement of the pipe insulation and the application of twin or triple pipes [2]. However, lower operation temperatures promise the higher impact compared to material changes in the pipe systems.

For the determination of steady-state heat losses, analytic solutions [3] and explicit solutions for specific geometries are available [4], [5]. The explicit solution of Wallentén is implemented in DIN EN 13941-1, which represents the state of the art for the heat loss calculation in district heating [6]. Wallentén proposes an explicit solution for one or two insulated pipes and twin pipes in the ground by applying the multipole method [5]. Kvisgaard and Hadvig introduce a corrected depth for the pipe axis to consider the heat transfer coefficient at the ground surface [4]. This assumption is also adapted in DIN EN 13941-1 [6]. The model of Kvisgaard and Hadvig has been evaluated by Oppelt et al. for DH and DC alication. In [7] a maximum deviation of 2.0-2.7\% for $\mathrm{DH}$ and 3.8-6.2 \% for DC was reported for the Kvisgaard/Hadvig model compared to simulations with the finite volume method in the case of two insulated single pipes.

Bøhm reviewed different methods for the calculation of steady-state heat losses and observed the undisturbed temperature of the ground as a critical value for the existing steadystate models. In his study, he did experiments and FEM simulations to find the location of an undisturbed ground temperature that can be applied in the steady-state theory to achieve acceptable accuracy. He found the location of this temperature approximately at the top of the casing for preinsulated pipes [8]. However, other researchers showed a measurable increase of the temperature near to DH pipes in the field [9], [10]. Another factor is the change in the near-surface temperature field due to climate change, urbanization and thermal exposure of the soil. Henning and Limberg found a ground temperature rise of more than $4 \mathrm{~K}$ in urban regions compared to rural regions in Berlin [11].

Regarding low temperature $\mathrm{DH}$, two effects have to be considered: The decrease of the supply (and return) temperature on the one hand and the decrease of temperature gradient between the return and supply pipe on the other hand. The reduction of the supply temperature level goes along with a significant reduction of the absolute heat losses of the system. The decrease of temperature gradient between the supply and return pipe reduces the transferred heat energy to the consumer. This loss of performance could be compensated by the trend of low energy buildings [1]. Strategies to supply existing buildings with temperatures below $70{ }^{\circ} \mathrm{C}$ are described in [12]. In this context the relative heat losses may be the main design value for new DH generations.

The relative heat losses are usually calculated depending on the annual heat consumption [13] or by a detailed modelling of the specific network [14], [15]. If no measurements of the consumption data are available, the estimation of the annual demand for space heating and domestic hot water is prone to errors [13], [14]. The study proposes an approach to estimate 
relative heat losses and gains by applying steady-state heat loss models. The calculation method can easily be adapted by the network operator to get a first impression of the network efficiency and capacity required for the heat production. In the following study, the relative heat losses are calculated with the proposed method and the results are compared for different generations DH networks and DC. Heating and cooling networks in Hamburg and surroundings have been selected to create realistic boundary conditions for the calculations.

\section{Methodology}

In the following, the database, the heat loss models and the model parameters applied for the calculations will be described.

\subsection{Database}

Hamburg's DH network and several other local heating networks are covering about a quarter of the heating demand of the city. The thermal register of Hamburg provides an overview of the heating networks and operators [16]. For the investigation of the heat losses, different heat networks are selected that meet the temperature requirements for the second, third and fourth DH generations [1]. Hamburg's DH network provides a supply temperature of $133{ }^{\circ} \mathrm{C}$ for the standard outer temperature of $-12{ }^{\circ} \mathrm{C}$ for Hamburg according to the national annex of DIN EN 12831 [17]. Due to this high temperature level, Hamburg's DH network is classified as $2^{\text {nd }}$ Generation DH. To represent the $4^{\text {th }}$ Generation $\mathrm{DH}\left(T_{S}<70{ }^{\circ} \mathrm{C}\right)$, the supply and return temperatures of a new residential area 'Waisengärten' in Schwerin, a city in northern Germany, have been selected for the study. The new residential buildings in the area of 'Waisengärten' is operated by Stadtwerke Schwerin GmbH, the public utility provider of Schwerin [18]. The energy concept for the new buildings combines geothermal heat supply with home stations to regulate the domestic hot water temperature [19].

The temperatures of the district and local heating networks selected for this study are taken from the official technical connection conditions of the network operators [18], [20]-[22] and are summarized in Table 1. The return temperatures in the official technical connection conditions are maximum return temperatures allowed by the operators. For the following investigation, a winter and summer case are considered to investigate the relative heat losses and gains of the systems.

TABLE 1. Selected HeAting AND COOLING NeTwORKS

\begin{tabular}{lccc}
\hline System operator & $\begin{array}{l}\text { Supply/return } \\
\text { temperature winter case } \\
\left(\mathbf{- 1 2}{ }^{\circ} \mathbf{C}\right)\end{array}$ & $\begin{array}{c}\text { Supply and return } \\
\text { temperature summer case } \\
\left(\mathbf{2 0}{ }^{\circ} \mathbf{C}\right)\end{array}$ & $\begin{array}{c}\text { District Heating } \\
\text { Generation according to } \\
\text { Lund } \text { et al. } \text { [1] }\end{array}$ \\
\hline Wärme Hamburg GmbH & $133 / 60^{\circ} \mathrm{C}$ & $90 / 20{ }^{\circ} \mathrm{C}$ & $2^{\text {nd }}$ \\
Innogy SE & $100 / 55^{\circ} \mathrm{C}$ & $69 / 20{ }^{\circ} \mathrm{C}$ & $3^{\text {rd }}$ \\
HanseWerk Natur GmbH & $80 / 45^{\circ} \mathrm{C}$ & $70 / 45^{\circ} \mathrm{C}$ & $3^{\text {rd }}$ \\
Stadtwerke Schwerin GmbH & $56 / 35^{\circ} \mathrm{C}$ & $56 / 35^{\circ} \mathrm{C}$ & $4^{\text {th }}$ \\
Wärme Hamburg GmbH & $8 / 15^{\circ} \mathrm{C}$ & $6 / 12^{\circ} \mathrm{C}$ & - \\
(Cooling network) & & & \\
\hline
\end{tabular}

A higher accuracy for determination of heat losses and gains can be obtained by knowing the ground temperature profile [23]. Therefore, historical weather data of Hamburg listed in DIN 4710:2003-01 [24] has been applied in the steady state heat loss models presented in section 2.2. The ground temperatures in January and July are representative for the winter 
and summer case. For the sake of a classification the resulting temperature profiles for Hamburg were drawn together with generalized curves according to Dahlem in Fig. 1.

It is important to point out that the weather data summarized in DIN 4710:2003-01 [24] is the average temperature for the years 1961-1990. Current weather data from the German Weather Service (Deutscher Wetterdienst) [25] suggests that the ground temperatures slightly increased in the last decades and the ambient temperature can rise up to $35^{\circ} \mathrm{C}$ during the summer season.

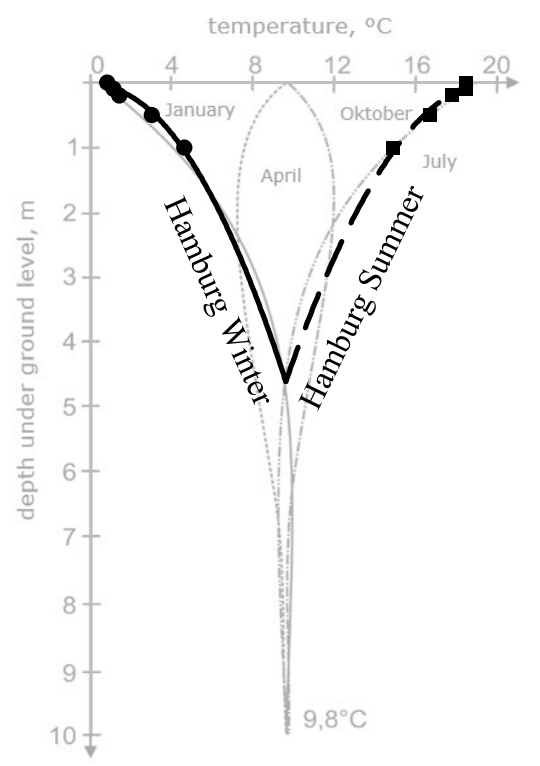

Fig. 1. Ground temperature profiles of the city of Hamburg compared with curves according to Dahlem without ground water [23], [24].

\subsection{Model for Steady-State Heat Loss}

District heating networks usually consist of two insulated symmetrical buried pipes with a circular cross-section as shown in Fig. 2. For the calculation of the steady-state heat losses, pure heat conduction is usually assumed, while convection, moisture transport and phase changes are neglected. Other assumptions are homogeneous material properties and no thermal resistances of the medium pipe and casing [10]. Radial heat conduction through the insulation to the ground and between the pipes is the process described by the most steadystate heat loss models for DH application. In the following, the term 'heat loss' refers to the length-related heat loss in $\mathrm{W} / \mathrm{m}$ if not otherwise specified in the text. 


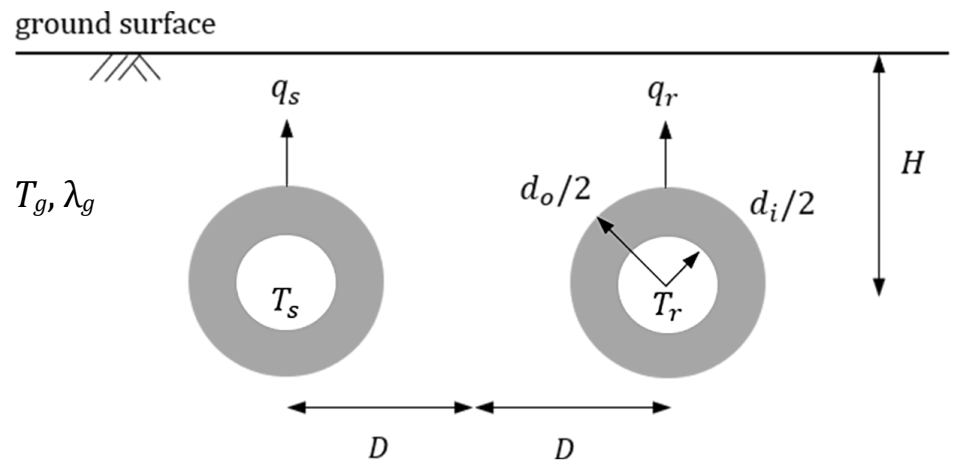

Fig. 2. Geometry of two insulated pipes in the ground.

Wallentén describes the heat loss of each DH pipe as a superposition of symmetrical and anti-symmetrical heat losses referring to the multipole method [3]. Thus, the heat losses of the supply and return pipe can be calculated according to Eq. (1) and Eq. (2).

$$
\begin{aligned}
& q_{s}=q_{s y m, s}+q_{a, s} \\
& q_{r}=q_{s y m, r}-q_{a, r}
\end{aligned}
$$

The symmetrical and anti-symmetrical heat losses (3) and (4) can be calculated by applying the temperatures $T_{s y m}$ and $T_{a}$ defined in Eq. (5) and Eq. (6).

$$
\begin{gathered}
q_{\text {sym }}=\left(T_{\text {sym }}-T_{g}\right) \cdot 2 \pi \lambda_{g} \cdot h_{\text {sym }} \\
q_{a}=T_{a} \cdot 2 \pi \lambda_{g} \cdot h_{a} \\
T_{s y m}=\frac{T_{s}+T_{r}}{2} \\
T_{a}=\frac{T_{s}-T_{r}}{2}
\end{gathered}
$$

The first-order multipole formula to calculate the reciprocal of the heat loss factor for the symmetrical problem is defined in Eq. (7). The formula for the anti-symmetrical heat loss factor is given in [5]. The dimensionless thermal resistance parameter $\beta$ is defined in Eq. (8).

$$
\begin{gathered}
h_{s y m}^{-1}=\ln \left(\frac{4 H}{d_{o}}\right)+\beta+\ln \left(\sqrt{1+\left(\frac{H}{D}\right)^{2}}\right)-\frac{\left(\frac{d_{0}}{4 D}\right)^{2}+\left(\frac{d_{0}}{4 H}\right)^{2}+\left(\frac{d_{0}^{2}}{16 \cdot\left(D^{2}+H^{2}\right)}\right)}{\frac{1+\beta}{1-\beta}+\left(\frac{d_{0}}{4 D}\right)^{2}} \\
\beta=\frac{\lambda_{g}}{\lambda_{i}} \ln \left(\frac{d_{o}}{d_{i}}\right)
\end{gathered}
$$

Wallentén quantifies the relative errors of the calculated heat losses as less than $0.5 \%$, when the first order formulae are used [5]. For the following analysis, the Wallentén and 
Kvisgaard/Hadvig model are applied to calculate the system heat losses. The two models differ in the calculation of the thermal soil resistance and in the value for the ground temperature. The corrected buried depth implemented by Kvisgaard and Hadvig to consider the heat transfer coefficient at the soil surface is defined in Eq. (9). For a detailed description of the Kvisgaard/Hadvig model refer to [4].

$$
H^{*}=H+0.0685 \cdot \lambda_{g}
$$

The ground temperature applied for the heat loss calculations is a key difference between the Wallentén and Kvisgaard/Hadvig model. Wallentén proposes the temperature on the ground surface, while Kvisgaard and Hadvig apply the temperature at the ground level of the pipe axis at installation depth. To investigate the influence of the ground temperature on calculated heat losses, the results obtained by using the original models are presented among the results in section 3. Bøhm investigated the location of an undisturbed ground temperature for steady-state heat loss calculation to achieve accurate results. The undisturbed ground temperature position for preinsulated pipes found by Bøhm corresponds to the ground temperature at the top of the casing and is applied in this study. For this purpose, the function equation for the city of Hamburg derived using the weather data in DIN 4710:2003-01 is applied [24].

To calculate the relative heat losses, the sum of the length related heat losses (1) and (2) is divided by the maximum amount of heat transported in the network according to the basic equation of thermodynamics (10). The relevant cross-sectional area $A$ is the cross-sectional area of the water pipe. Due to the stationary condition, only the full load case is considered. According to the AGFW (German District Heating Association), the steady-state condition is only applicable for network lengths below $10 \mathrm{~km}[26]$.

$$
\dot{Q}=\rho \cdot A \cdot v \cdot c_{p} \cdot\left(T_{s}-T_{r}\right)
$$

The resulting parameter proposed in this study to estimate relative heat losses is a percentage heat loss per meter of pipe length according to Eq. (11). The corresponding unit is $\% / \mathrm{m}$.

$$
\tilde{q}=\frac{q_{s}+q_{r}}{\dot{Q}} \cdot 100 \%
$$

\subsection{Model Parameters}

The calculation parameters are selected according to typical operating conditions of DH networks. Key parameters are summarized in Table 2. The steel pipe dimension of DN 200 can be applied for district heating and cooling; the dimensions of the pipe and insulation comply with the standards DIN EN 253 and DIN EN 17415-1 [27], [28]. 
TABle 2. CAlculation PARAmeters

\begin{tabular}{lll}
\hline Parameter & Symbol & Value \\
\hline Heat conductivity of the ground & $\lambda_{g}$ & $1.2 \mathrm{~W} /(\mathrm{mK})$ \\
Heat conductivity of the insulation & $\lambda_{i}$ & $0.027 \mathrm{~W} /(\mathrm{mK})$ \\
Cross-sectional area & $A$ & $0.0346 \mathrm{~m}^{2}$ \\
Heat capacity of water & $c_{p}$ & $4190 \mathrm{~J} /(\mathrm{kgK})$ \\
Inner insulation diameter & $d_{i}$ & $0.219 \mathrm{~m}$ \\
Outer insulation diameter & $d_{o}$ & $0.315 \mathrm{~m}$ \\
Distance between the pipe axes & $2 D$ & $0.565 \mathrm{~m}$ \\
Buried depth & $H$ & $0.9575 \mathrm{~m}$ \\
Flow velocity & $v$ & $1 \mathrm{~m} / \mathrm{s}$ \\
\hline
\end{tabular}

\section{Results}

For the networks listed in Table 1 the absolute heat losses and gains calculated with the Wallentén and Kvisgaard/Hadvig model are visualized in Fig. 3 and Fig. 4, each for winter and summer case. The results presented in Fig. 2 and Fig. 3 are obtained by applying the ground temperatures proposed by the original authors to visualize the influence of the selected ground temperature on the heat losses. For the Wallentén model, a ground surface temperature of $0.8^{\circ} \mathrm{C}$ (winter) and $18.5^{\circ} \mathrm{C}$ (summer) and for the Kvisgaard/Hadvig model $4.6^{\circ} \mathrm{C}$ (winter) and $14.9{ }^{\circ} \mathrm{C}$ (summer) are applied [24].

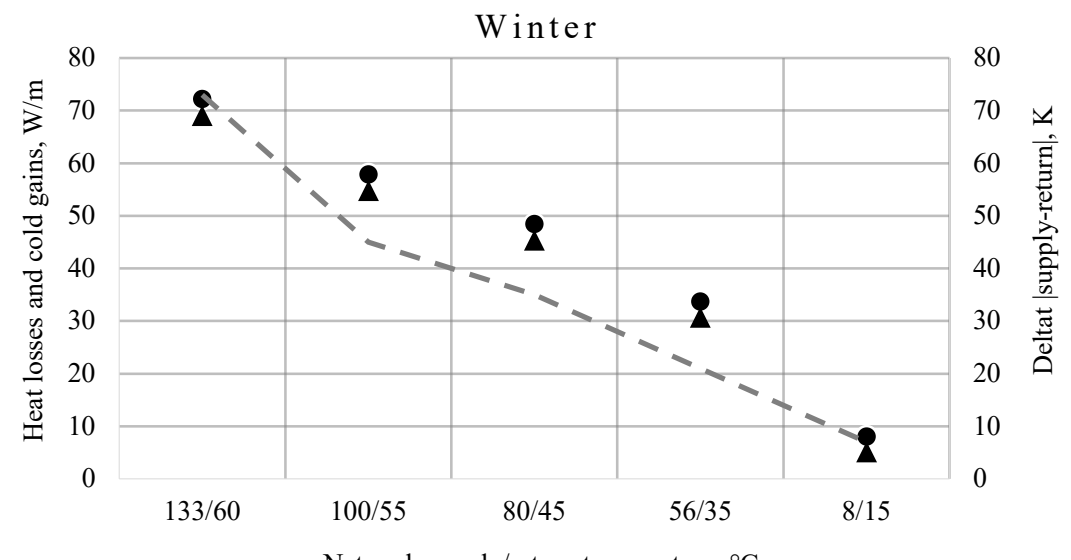

Network supply/return temperature, ${ }^{\circ} \mathrm{C}$

- Wallenten model $\quad \Delta \quad$ Kvisgaard/Hadvig model $\quad-\quad--$ deltaT supply-return

Fig. 3. Calculated heat losses - winter case. 


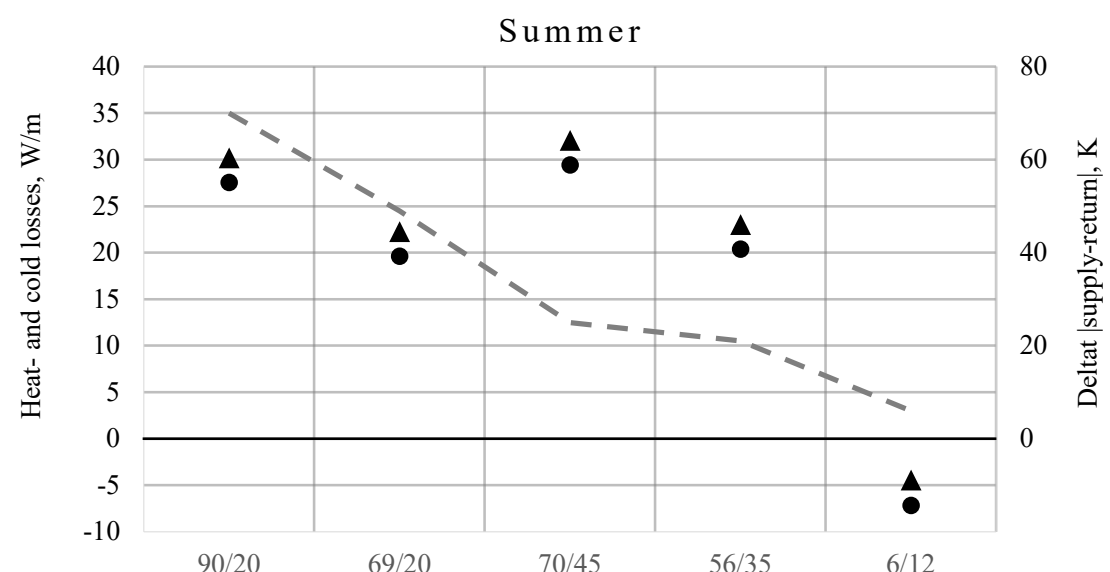

Network supply/return temperature, ${ }^{\circ} \mathrm{C}$

- Wallenten model $\quad$ Kvisgaard/Hadvig model $\quad-=-$ deltaT supply-return

Fig. 4. Calculated heat and cold losses - summer case.

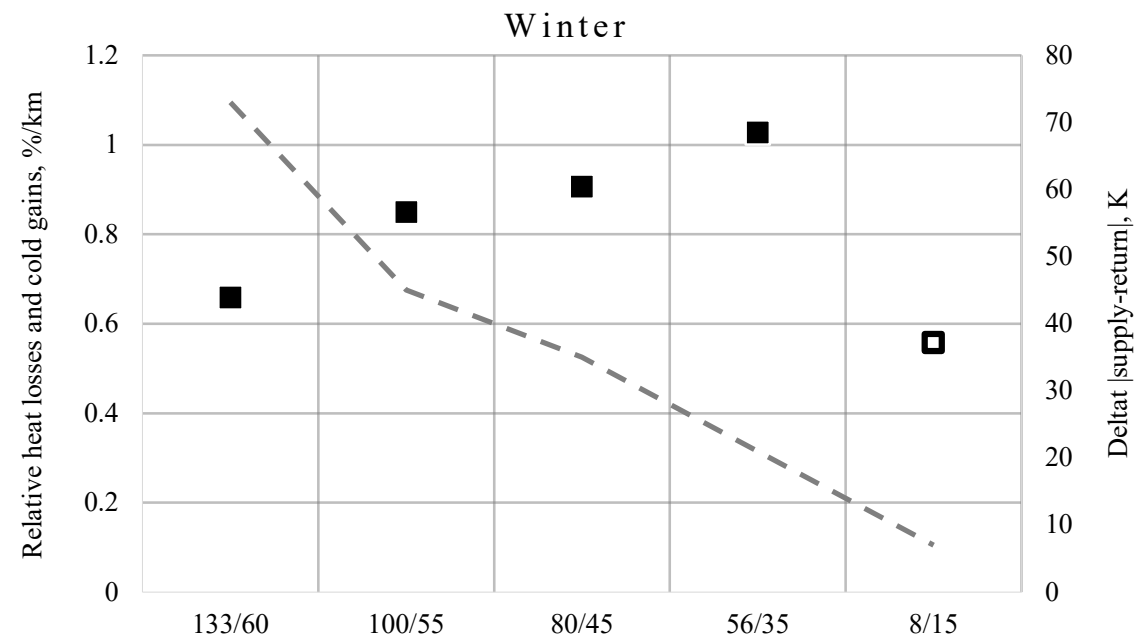

Network supply/return temperature, ${ }^{\circ} \mathrm{C}$

- rel. heat losses $\quad$ rel. cold gains $\quad-\quad-$ - delta T supply-return

Fig. 5. Calculated relative heat losses - winter case.

The resulting heat losses obtained with the Wallentén and Kvisgaard/Hadvig model show a constant deviation of about $3 \mathrm{~W} / \mathrm{m}$. The relative deviation between the calculated heat losses increases with decreasing temperature gradient between the water pipe and ground temperature. The relative deviation has a range of $4-12 \%$ for the $\mathrm{DH}$ and reaches the maximum value of $38 \%$ for DC. The relative deviation between the two models is less than $0.5 \%$ if the same value is applied for the ground temperature. 
The Wallentén model with the undisturbed ground temperature proposed by Bøhm is applied to determine the relative heat losses. The ground level of the top of the pipe casing corresponds to a depth of $0.8 \mathrm{~m}$. The undisturbed ground temperature results in $4{ }^{\circ} \mathrm{C}$ for the winter case and $15.5^{\circ} \mathrm{C}$ for the summer case. The resulting relative heat losses per kilometre pipe length are presented in Fig. 5 and Fig. 6.

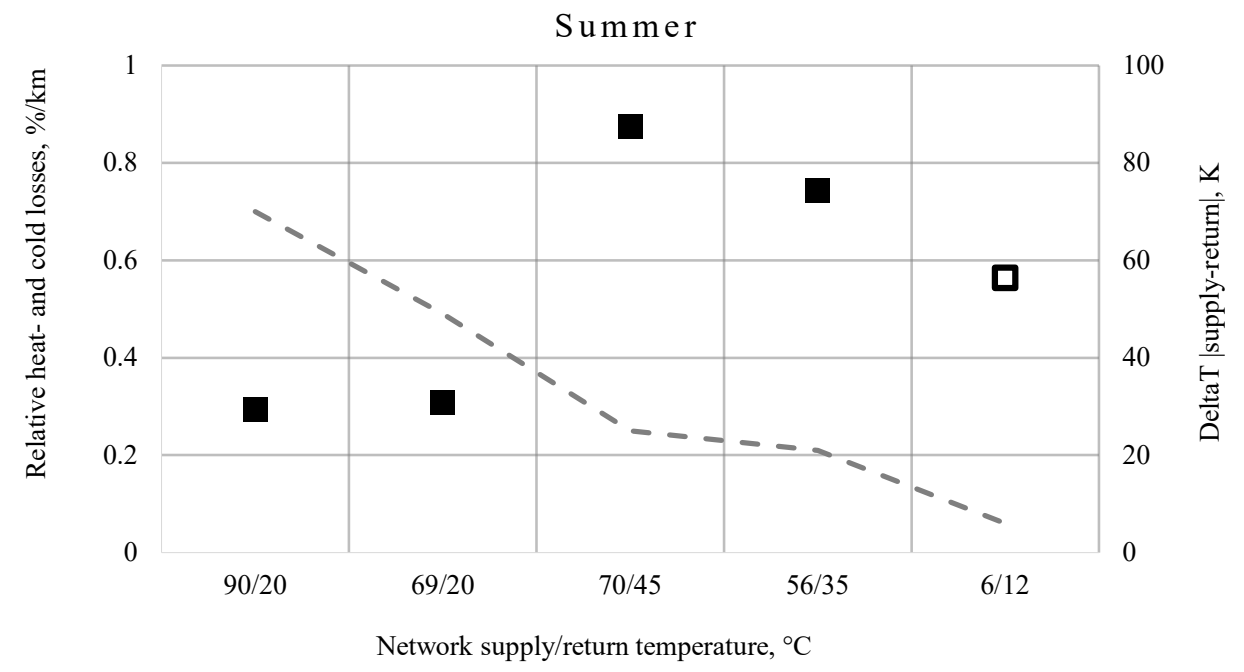

- rel. heat losses $\quad$ rel. cold losses $\quad-\quad-$ deltaT supply-return

Fig. 6. Calculated relative heat- and cold losses - summer case.

\section{DiscusSION}

In the previous section the results obtained by the Wallentén and Kvisgaard/Hadvig model for steady-state heat losses of different heating and one cooling network have been presented in Fig. 3 and Fig. 4. A constant deviation of about $3 \mathrm{~W} / \mathrm{m}$ occurs between the results due to different ground temperatures implemented in the original models. As the heat losses are constantly decreasing with decreasing temperature gradient between the medium pipe and ground temperature, the relative deviation of the heat losses rises up to $38 \%$ for the DC case. These results of the different steady-state models for low temperature DH and DC show the significance of an accurate selection of the undisturbed ground temperature for these applications. In this context, an optimized ground temperature position for the $4^{\text {th }}$ Generation $\mathrm{DH}$ and for DC should be further investigated. The overall trend of decreasing heat losses for newer DH generations due to the decrease of the driving temperature gradient between the pipe and the ground is confirmed in the results for the winter and summer case. The outliners for the $90 / 20{ }^{\circ} \mathrm{C}$ and $69 / 20{ }^{\circ} \mathrm{C}$ networks in the summer can be explained by the lower return temperature of $20^{\circ} \mathrm{C}$ compared to the other investigated heating networks.

In this work, the percentage heat loss per meter of pipe length is proposed as a parameter to estimate the relative heat losses and gains of a system. In Fig. 5 and Fig. 6 the relative heat losses are presented for a winter and summer case.

In the winter case, the relative heat losses of the investigated heating networks increase, while the temperature level is decreasing. As the absolute heat losses decrease as shown in Fig. 3, the influence of the slope of the transported heat flux $\dot{Q}$ causes the rising trend. For 
the DC network the lowest relative heat losses occur, even though the transported heat flux is factor 10 smaller than for the $133 / 60{ }^{\circ} \mathrm{C}$ case. The relative heat losses of DC come out as approximately half of the relative heat losses of the $4^{\text {th }}$ Generation heating network. This result highlights the need of a proper design strategy for low temperature heating networks to achieve good energy and economic efficiency.

In the summer case the same trend of rising relative heat losses can be observed for the $90 / 20{ }^{\circ} \mathrm{C}, 69 / 20{ }^{\circ} \mathrm{C}$ and $70 / 45^{\circ} \mathrm{C}$ system. The jump between the values for $69 / 20{ }^{\circ} \mathrm{C}$ and $70 / 45^{\circ} \mathrm{C}$ can be explained by the higher heat losses due to the higher return temperature of the $70 / 45^{\circ} \mathrm{C}$ network. According to Fig. 6 (summer case), the relative heat losses of the $4^{\text {th }}$ Generation heating network $\left(56 / 35^{\circ} \mathrm{C}\right)$ are lower than for the $70 / 45^{\circ} \mathrm{C}$ system, but higher than for the $90 / 20{ }^{\circ} \mathrm{C}$ and $69 / 20{ }^{\circ} \mathrm{C}$ network. This result shows the impact of the system return temperature level.

With rising network length, the heat losses increase linearly. A variation of the network length shows, that for a network length of 20000 meters the relative heat losses reach a magnitude of up to $20 \%$ for the $56 / 35^{\circ} \mathrm{C}$ system. This high amount of heat loss would cool down the water flow. This result confirms the limits of the application of the steady-state condition for large networks.

Another important design factor is the flow velocity that has been assumed to be constant in this study for comparability reasons. In real operation, the velocity changes constantly, depending on the operational requirements. By adjusting the flow velocity, the transported heat flux in the system can be increased. However, increased flow velocity goes along with higher energy demand for distribution pumps. An exergetic analysis should be part of a subsequent sensitivity analysis.

\section{CONCLUSion}

In this study, the relative heat losses and gains have been investigated for networks of different DH generations and one DC network. For the calculation of steady-state heat losses, the models of Wallentén and Kvisgaard/Hadvig have been applied. The resulting relative deviation due to the different soil temperature applied in the models, reached a maximum value of $38 \%$ for the DC. The results show the potential for new criteria for ground temperature selection to improve the accuracy of heat- and cold loss calculation for DC. These criteria could be integrated in the new district cooling standard, that is currently still under development.

The approach proposed in the study enables to estimate the relative heat- and cold losses per pipe length for specific operational conditions by using steady-state heat loss models. The proposed calculation method can be easily performed by the system operator to get a first impression of the network efficiency and capacity required for the heat production.

The results for the relative heat losses and gains point out the imbalance between the reduction of heat losses on the one side and the reduction of the transported heat flux on the other side. Concerning the reduction of the temperature level of newer DH generations, new design parameters are required to find an optimized balance between these values. A noticeable dependency of relative heat losses on the return temperature level was evident in the results. Measures to reduce the return temperature have a positive effect on both the heat losses and the system heat flux. Further analysis of possible heating effects on the return flow in the summer due to rising near-surface soil temperature will be a topic of subsequent research.

The maximum value of the relative heat losses for the $4^{\text {th }}$ Generation DH during the winter season highlights the rising influence of the reduced transported heat flux on the energy 
efficiency of newer DH generations. Especially for long DH networks a design strategy is required to avoid energy wasting and achieve monetary savings. As a next step, a transient determination of the relative heat losses and gains should be carried out with experimental measured values and FEM analysis to verify the calculated trends.

\section{ACKNOWLEDGEMENT}

The work reported is self-funded by the HafenCity University. The authors declare no conflict of interest.

\section{REFERENCES}

[1] Lund H., et al. 4th Generation District Heating (4GDH) Integrating smart thermal grids into future sustainable energy systems. Energy 2014:68:1-11. https://doi.org/10.1016/j.energy.2014.02.089

[2] Bøhm B., Kristjansson H. Single, twin and triple buried heating pipes: on potential savings in heat losses and costs. International Journal Energy Res 2005:29:1301e12. https://doi.org/10.1002/er.1118

[3] Claesson J., Bennet J., Hellström G. Multipole method to compute the conductive heat flows to and between pipes in a cylinder. Lund: Department of Building Technology and Mathematical Physics, 1987.

[4] Kvisgaard B, Hadvig S. Varmetab fra fjernvarmeledninger (Heat loss from pipelines in district heating systems). Lungby: DTU, 1980. (in Danish)

[5] Wallentén P. Steady-state heat loss from insulated pipes. Lund: Department of Building Physics, Lund Institute of Technology, 1991.

[6] DIN EN 13941-1:2019 District heating pipes - Design and installation of thermal insulated bonded single and twin pipe systems for directly buried hot water networks - Part 1: Design.

[7] Oppelt T., Urbaneck T., Platzer B. New model for calculating the heat flow through the walls of buried parallel pipes. EuroHeat\&Power 2013:10(3):38-43.

[8] Bøhm B. On transient heat losses from buried district heating pipes. International Journal Energy Res 2000:24(15):1311-1334. https://doi.org/10.1002/1099-114X(200012)24:15<1311::AID-ER648>3.0.CO;2-Q

[9] Henögl O. Vergleich der thermischen Eigenschaften von verschiedenen bodenmechanisch geeigneten Bettungsmaterialien für Fernwärmeleitungen (Comparison of thermal properties of different soil mechanical bedding materials suitable for district heating pipelines). 7. Kolloquium Bauen in Boden und Fels, Germany, 2010. (in German)

[10] Rosa A. D., Li H., Svendsen S. Method for optimal design of pipes for low-energy district heating, with focus on heat losses. Energy 2011:36(5):2407-2418. https://doi.org/10.1016/j.energy.2011.01.024

[11] Henning A., Limberg A. Veränderung des oberflächennahen Temperaturfeldes von Berlin durch Klimawandel und Urbanisierung (Changes in the near-surface temperature field of Berlin due to climate change and urbanization) Brandenburgische geowissenschaftliche Beiträge 2012:19:81-92. (in German)

[12] Nord N., Ingebretsen M., Tryggestad I. Possibilities for Transition of Existing Residential Buildings to Low Temperature District Heating System in Norway. Proceedings of the 12th REHVA World Congress 2016:3:22-25.

[13] Masatin V., Latõšev E., Volkova A. Evaluation Factor for District Heating Network Heat Loss with Respect to Network Geometry. Energy Procedia 2016:95:279-285. https://doi.org/10.1016/j.egypro.2016.09.069.

[14] Rebollar J. V., Himpe E., Janssens A. Performance evaluation of a low temperature district heating system based on simulation, uncertainty and sensitivity analysis. International Building Performance Simulation, Proceedings 2013:3809-3816.

[15] Olsen P. K., et. al. A New Low-Temperature District Heating System for Low Energy Buildings. Presented at the $11^{\text {th }}$ International Symposium on District Heating and Cooling, Reykjavik, Iceland, 2008.

[16] Wärmekataster für die Freie und Hansestadt Hamburg (Heat register for the Free and Hanseatic City of Hamburg) [Online]. [Acessed 31.01.2021]. Available: https://www.hamburg.de/energiewende/waermekataster/8342506/waermekataster-fuer-die-fhh/_(in German)

[17] DIN/TS 12831-1:2020-04 Method for calculation of the room heat load-Part 1: National addition to DIN EN 12831-1.

[18] TAB-HW Stadtwerke Schwerin GmbH (Technical connection conditions Stadtwerke Schwerin GmbH). Schwerin: Stadtwerke Schwerin GmbH, 2015. (in German)

[19] Landeshauptstadt Schwerin. Energetische Stadtsanierung Schwerin (Energy-related urban redevelopment Schwerin). Schwerin: Landeshauptstadt Schwerin, 2012. (in German)

[20] TAB-HW HanseWerk Natur GmbH (Technical connection conditions HanseWerk Natur GmbH). Hamburg: HanseWerk Natur GmbH, 2020. (in German)

[21] TAB-HW Wärme Hamburg GmbH (Technical connection conditions Wärme Hamburg GmbH). Hamburg: HanseWerk Natur GmbH, 2020. (in German)

[22] RWE Group. Technische Anschlussbedingungen für den Anschluss an das Fernwärmenetz Hamburg RahlstedtMeiendorf der innogy SE (Technical connection conditions innogy SE). Essen: RWE Group, 2014. (in German) 
[23] Dahlem K. H. Der Einfluß des Grundwassers auf den Wärmeverlust erdreichberührter Bauteile (The effect of groundwater on the heat loss of building parts in contact with the ground). Thesis. Kaiserslautern: University of Kaiserslautern, 2000. (in German)

[24] DIN 4710:2003-01 Statistics on German meteorological data for calculating the energy requirements for heating and air conditioning equipment.

[25] DWD Climate Data Center (CDC): Historische stündliche Stationsmessungen der Erdbodentemperatur für Deutschland (Historical hourly measurements of ground temperature for Germany). Version v006. Offenbach: DWD CDC, 2018. (in German)

[26] AGFW FW 440. Teil 2. Hydraulic calculation of heating water district heating networks - Fundamentals of steadystate calculation, characteristic values and calculation variables. Frankfurt am Main: AGFW, 2012.

[27] DIN EN 253:2020-03 District heating pipes - Bonded single pipe systems for directly buried hot water networks Factory made pipe assembly of steel service pipe, polyurethane thermal insulation and a casing of polyethylene.

[28] DIN EN 17415-1: 2019 District cooling pipes - Bonded single pipe systems for directly buried cold water networks Part 1: Factory made pipe assembly of steel or plastic service pipe, polyurethane thermal insulation and a casing of polyethylene. 